\title{
"Do It the Russian Way": Narratives of the Russian Revolution in European History Textbooks
}

\author{
Marharyta Fabrykant
}

The history of the Russian Revolution is featured in a multitude of narratives, each of them double-sided. On the one hand, the Russian Revolution doubtlessly belongs to world history as one of the inaugurating and probably most impactful events of the twentieth century. On the other hand, as manifested in its very name, the Russian Revolution is a momentous event in the history of Russia. This tension between global and national history accounts for the recurrent motif in many discussions of the Russian Revolution-the question to what extent it represents the logic of global historical trends, as opposed to the alleged peculiarity of Russia's history and identity. Peter Holquist in particular has argued that it was the European experience of WWI that defined the assumptions shared by Bolsheviks and their opponents. Many wartime practices and institutional arrangements, such as the mobilization of resources, came to be accepted as normal rather than temporary and were eventually incorporated into the Soviet regime. ${ }^{1}$

In the current debates about the uniqueness versus the universality of the Russian historical experience, the focus has shifted to the post-Soviet period. At present, researchers who view contemporary Russia as similar to other countries (for example, to countries at roughly the same level of economic development) position themselves as a small minority. ${ }^{2}$ Their more numerous opponents focus on what they see as Russia's unique features. The latter include supporters and opponents of the Russian Sonderweg, both substantiating their position primarily with reference to the recent Russian conservative backlash. ${ }^{3}$ In retrospect, however, it is tempting to view this turn as the first link in the chain of similar conservative victories shifting first to eastern, then to western Europe, and then, on a truly global scale, even to the US. This development runs parallel to the events triggered by the Russian Revolution, when Russia was regarded by many as having started the global spread of a newly-dominant ideology, albeit at that time not a right-wing but a left-wing one. Since the similarity is not in the substance but in the form of the chain of events, it makes sense to approach the history of the Russian Revolution as a narrative. Revealing the narrative structures of the Russian Revolution in contemporary history-writing may shed some light on the socially-shared framework of understanding the current conservative revolution.

This work is an output of a research project implemented as a part of the Basic Research Program at the National Research University Higher School of Economics (HSE). The primary sources for the research were accessed due to the support from the library of the Georg Eckert Institute for Textbook Research.

1. Peter Holquist, Making War, Forging Revolution: Russia's Continuum of Crisis, 19141921. (Cambridge, Mass., 2002).

2. Andrei Shleifer and Daniel Treisman, "A Normal Country: Russia after Communism” The Journal of Economic Perspectives 19, no. 1 (Winter 2005): 151-74.

3. Thomas Ambrosio, Authoritarian Backlash: Russian Resistance to Democratization in the Former Soviet Union (London, 2016). 
This study aims to reveal modes of narration about the Russian Revolution prevalent in the contemporary European school textbooks. Textbooks are important, first, because they usually present a shared and more-or-less agreed-upon view of history, rather than ideas of particular historians, and second, because school textbooks are the only genre of historical writing to which most people are exposed, and moreover, exposed in their formative years. ${ }^{4}$

The sample consists of 101 textbooks from 22 European states, including all the Slavic countries, published between 2000 and 2015 and currently in use at secondary and high schools (the list of all the textbooks sorted by countries is presented in the Appendix). In most countries, the textbooks were designed for comprehensive world history courses with a focus on the country where a given textbook is used. In some east European countries, such as Belarus and Ukraine, world history and national history are taught as two different courses, and both of them cover the Russian Revolution. Most textbooks in the sample are parts of multi-volume sets covering the whole of world history from ancient times to the present and is intended for many years of study. The place of WWI in the curricula varies considerably across countries; in general, the primary target audience of the textbook chapters covering the Russian Revolution is aged between 13 and 17. The length of these chapters varies from 2 pages for some west European textbooks to 10-15 pages for textbooks published in parts of the former Russian Empire.

The results section of this paper considers in turn the three questions of the study-how the textbooks narrate the events, the causes, and the historical significance of the Russian Revolution. The final section of the paper discusses the reasons and implications of the key finding of the study-that the Russian Revolution is being narrated in European textbooks not as a peculiarly Russian event determined solely by country-specific causes, but as an extreme, indeed revolutionary outcome of the general causal logic of the WWI.

\section{Russian Revolution: What Textbooks Say Actually Happened}

Most European textbooks cover the Russian Revolution within or, in some cases, immediately after the chapters dedicated to WWI. While in Russia's history WWI was overshadowed by the October Revolution, from the European perspective the Russian Revolution is a smaller part of the story of the WWI. While chronologically obvious, the need to incorporate the story of the Russian Revolution into the broader narrative of the WWI poses a challenge to the narrative structure adopted in virtually all textbooks. The levels at which the events occur are hierarchically organized, mostly at two levels-national and global-with sometimes one or two intermediary regional levels, such as the Balkans. The Russian Revolution disrupts the logic of presenting history through a national paradigm while not easily speaking to the global, rather introducing the event as taking place in a different country. In some textbooks, most notably Polish and German ones, this challenge is met by

4. Stuart J. Foster and Keith Crawford, eds., What Shall We Tell the Children?: International Perspectives on School History Textbooks (Greenwich, 2006). 
narrating the revolutions in their own countries immediately after the paragraphs on the Russian Revolution. Swiss textbooks extend the story of the Russian Revolution into the late 1930s and relate it to a general discussion on dictatorships as consequences of war. Some Spanish and Italian textbooks place the story of the Russian Revolution outside the chapters on WWI, albeit immediately after them. Most textbooks, however, zoom in on the internal Russian situation, sometimes going back to the early years of the Russian Empire, and then zoom out with the treaty of Brest-Litovsk as a bridge to the continuation of the global history of WWI.

The Russian Revolution appears to be the most widespread name, although some German textbooks speak about a coup (Umsturz) or the conquest of power (Machteroberung), and some Spanish textbooks present the Soviet, not the Russian Revolution (la revolucion Sovietica). In many cases the headings of paragraphs introduce "the Russian Revolutions" (a Bosnian textbook even mentions "February and October Revolution" (Februarska i Oktobarska revolucija) as a single event, and in many such textbooks the February Revolution is covered in almost as much detail as the October Revolution. This neutrality is, however, not supported by visual supplements. Most photographs presented in the textbooks feature Tsar Nicholas II and his family, and then Vladimir Lenin, Lev Trotskii, and Iosif Stalin, but not Aleksandr Kerenskii or other characters related to the events of the February Revolution or the Provisional Government, or, when covering the Russian Civil War, the White Army generals. The historical caricatures included in these textbooks also present either Lenin or Trotskii. Thus, the concrete history of the Russian Revolution, visualized and personified, shrinks to the Bolshevik state replacing the old Romanov Empire with vague and unsubstantial occurrences in between. This kind of narrative assigns the significance to the events in retrospect and does not allow for differing interpretations. The readers are invited not to empathize with the participants of this turbulent and unpredictable period in history, but rather to learn some lessons from the story as a closed and completed linear sequence.

One reason for this didactic approach may lie in the unanimity of most textbooks across European countries on the key events constituting the Russian Revolution, or revolutions. Moreover, the evaluations of the events are also very similar. Most textbook authors agree that the Romanov dynasty was doomed and that the weak and incompetent rule of the last Tsar catalyzed the events; that the mass dissatisfaction with living conditions was wholly justified; but also that the Bolshevik revolution led to a bloody civil war and the establishment of the new Soviet state, and then to Stalin's totalitarian regime. The history of the Russian Revolution is presented as a history of intense and uniform desolation and misery, not as a history of turmoil created by what Peter Holquist calls the "revolutionary ecosystem"-a simultaneous appearance of many parties and actors from all parts of the political spectrum, which in itself is a rare occurrence in Russian history. Instead, the events of the Russian Revolution are portrayed as an inevitable link in the uninterrupted chain of Russia's history, without dead ends, random chances, or unfulfilled possibilities, arguably because of the near-universally shared understanding of what events comprise the Russian Revolution. The main 
question the textbook authors pose to their audiences regarding the Russian Revolution is not what, but why.

\section{Causes of the Russian Revolution(s)}

In most textbooks, the key question posed in the paragraphs on the Russian Revolution, or revolutions, is the question concerning its causes. Even though the sequence of events leading to and through the Russian Revolution appears inevitable, the specific causes remain unclear and are explicitly discussed. For an event of national history embedded into a global context, one would expect the causes to be classified as either country-specific or universal. The actual structure of narratives in European history textbooks, however, is not so simple.

At first glance, it seems that country-specific causes are at the forefront. The logic of zooming in on national history narratives requires setting up some historical background, and in most textbooks, these background details quickly assume causal significance. One such contextual feature of early twentieth-century Russia is what in many textbooks is explicitly defined as its "backwardness." 5 Some textbooks qualify this backwardness by presenting Russia as relatively backward compared to western Europe, or to other early twentieth-century superpowers. The main sphere where this Russian backwardness manifests itself according to nearly all textbooks is, predictably, the economy, which is aggravated with high social inequality. Many authors also add another dimension that in various ways refers to what in contemporary social-policy studies is called the quality of governance. Interestingly, no textbook specifically mentions the perennial issue of Russian corruption. Instead, the focus is not on bad intentions, but on general pervasive incompetence at all levels. This focus shows a defining feature of the narrative about the Russian Revolution-the lack of agency. The story of the Russian Revolution is a narrative without a protagonist, and that is why its events look chaotic and predetermined at the same time: there is nobody who could bring order to the chaos and find a different solution to the accumulated controversies and grievances. The main outcome of the revolution can be regarded as the emergence of a protagonist. Only near the end, when the Bolsheviks manage not only to seize, but also to hold power, does it become clear who was intended to become the main character and who the story was all about.

Another country-specific cause, raised mostly in textbooks from countries that used to be parts of the Russian Empire, such as Poland or Ukraine, is Russia's imperialism. These textbooks suggest that the rapid territorial growth of the Russian Empire throughout its entire history was a misguided attempt to shift public attention away from internal problems in the economy and governance, and that these problems made the state and society incapable of

5. For a recent discussion of interrelations between the Russian backwardness and the Russian Revolution, see Derek Offord, "From National Backwardness to Revolutionary Leadership: Alexander Herzen's Book On the Development of Revolutionary Ideas in Russia” in Rachel Hammersley, ed., Revolutionary Moments: Reading Revolutionary Texts (London, 2015), 117. 
dealing with the needs of the new territories. Imperialism is also featured in most textbooks as the main cause of WWI itself. This line of causal reasoning shows another feature of the narrative of the Russian Revolution-its structural similarity to the narrative of WWI as a whole, within which it is embedded. Imperialism, just like economic hardship, poor quality of governance, and the resulting loss of trust in national elites, is portrayed as characteristically Russian-but at the same time as emblematic of the period of the WWI in all of Europe. In Russia, according to this narrative, these negative tendencies started earlier, were accumulated at a higher rate, and therefore erupted on a larger scale. What for other countries was of short-term duration and changed significantly with the end of the war had started much earlier than the war itself in Russia. In the narrative of the Russian Revolution, WWI plays the same role as the shot in Sarajevo does in the narrative of the WWI-that of a tipping point. The explication of the causes of the Russian Revolution in textbooks shows the significance of Russia as the extreme case of all the most pernicious threats of the epoch.

\section{Significance of the Russian Revolution According to Textbooks}

Strangely enough, although the events of the Russian Revolution are narrated as logically inevitable and its causes discussed in universalist terms, most textbook authors fail to draw general conclusions about the overall historical significance of the Russian Revolution. An easy way of avoiding such conclusions is by returning to the larger narrative of WWI. Russia's withdrawal from the war as a result of the October Revolution serves as a convenient short-term consequence, allowing authors to zoom out into global history. Another set of immediate consequences includes country-specific events, such as the revolutions in Germany and the gaining of national independence by Poland. The significance of the revolution for Russia itself appears, albeit not explicitly, to be the exact opposite of what the revolutionaries themselves claimed. ${ }^{6}$ Instead of radical change, the point at which various textbook authors choose to end, or rather interrupt, the story of the Russian Revolution (ranging from the end of the Russian Civil War to the pinnacle of Stalinism), exemplifies the same Russian maladies that were first presented as the causes of the revolution-economic backwardness, chaotic and dictatorial governance, and imperialism.

The reasons why the textbooks do not discuss the significance of the Russian Revolution are twofold. First, and more obviously, all the textbooks analyzed were printed long after the collapse of the Soviet Union, which made the failure of the communist experiment apparent and looked upon Soviet history from start to finish as a the thing of the past. At a deeper level, however, I suggest that the failure to generalize upon the historical significance of the Russian Revolution relates to the inconsistency between approaches to imperialism at the evaluative and descriptive levels. While most textbooks

6. See Eugen Weber. "Revolution? Counterrevolution? What Revolution?,” Journal of Contemporary History 9, no. 2 (April 1974): 3-47 for the discussion of the blurred distinction between a revolution and its opposite. 
dedicate many pages to the atrocities of imperialism and its decisive role in what is repeatedly called "the suicide of Europe," their authors fail to place the history of the Russian Revolution within the conceptual framework of imperialism. ${ }^{7}$ The textbook authors do not answer, nor even pose the questions of why the Russian Empire, arguably the weakest of all the late nineteenth-century European empires, managed to survive the war and recreate itself within almost the same borders with a renewed legitimacy. Moreover, most textbook authors portray revolutionary Russia as a single uniform entity and pay hardly any attention to local peculiarities of the revolution in various parts of the Russian Empire. Even textbooks published in some of the former peripheries of the Russian Empire, such as Poland and Ukraine, pay no attention to other imperial peripheries. These omissions in the contemporary narratives of the Russian Revolution demonstrate on a larger scale the message contained within the narrative itself-the well-known motif in the literature about revolutions, namely their inability to fulfill the promise of change.

The narrative analysis of the story of the Russian Revolution in European history textbooks reveals a shared set of assumptions about the history of Russia and the historical role of revolutions. Most authors see the Russian Revolution as the ultimate outcome of Russia's accumulated problems over several centuries, eventually exploding when the whole European order broke apart. The Russian case is presented as neither wholly specific nor wholly universal, but a combination of both. As the weakest (what in textbooks is called "backward"), and therefore the most vulnerable of the major European powers, Russia internalizes "the suicide of Europe" and replays it within a single European country as a radical break with the past. The outcome of this clash between the internal Russian and external European circumstances is narrated as inevitable.

This deterministic interpretation is what makes the Russian Revolution stand apart from most other events of WWI. Narratives of the war and its causes, such as imperialism, colonialism, or nationalism emphasize, on the contrary, moral responsibility based on free choice. Not only the major empires, but smaller European states appear as free agents. Countries that entered the war soon after it began, such as Italy or Bulgaria, appear in textbooks as pragmatically considering which side to join, and their eventual decision is seen as in no way predetermined by these countries' past history. Many textbooks even consider individual responsibility of specific persons, from Kaiser Wilhelm II to Gavrilo Princip, and prompt students to ask themselves what they would do in these characters' places. The narrative of the Russian Revolution does not invite empathy or consideration of the possibility for alternate choices. The suffering of the Russian lower classes, unlike the horrors experienced by soldiers in the trenches of WWI, is described in sociological rather than psychological terms. In terms of literary genres, the narrative of WWI in textbooks is a human drama, and that of the Russian Revolution, an epic tragedy. Unlike the drama of WWI, the tragedy of the Russian Revolution has no clear

7. Mark R. Beissinger, “Soviet Empire as 'Family Resemblance', Slavic Review 65, no. 2 (Summer 2006): 294-303. 
beginning, since the causes go back for centuries, and no clear end, since the Russian Revolution, as presented in textbook, defined the key features of the Soviet regime, and contemporary Russia is still defined through its past as a post-Soviet country. The narrative of the Russian Revolution in European textbooks shows how history becomes identity-and how textbook authors' definition of Russia's identity as tragic "backwardness" unfolds in a specific way of narrating the country's history

These differences shed some light on contemporary European textbooks themselves and the kind of history they teach. Besides the discrepancy between the conceptual and the narrative sides of the story, as demonstrated by the inconsistency in applying the general notion of imperialism to the history of the Russian Empire, the textbooks share a more general and arguably more consequential drawback-the overemphasis on deterministic, retrospective, and external views on the most complicated historical events. While cognitively simple and emotionally charged experiences, such as the horrors of war or politicians' ambitions and aspirations, are justly narrated from the insider's perspective, the uncertainty and indeterminacy experienced by the contemporaries of the Russian Revolution fail to appear in textbooks. Instead, the history of the Russian Revolution, of all events, is presented, with the full force of hindsight, as linear and predetermined. In a world going through a new sequence of dramatic changes, this time the global rise in popularity is not of the extreme left-wing politics of the Russian Revolution, but of the extreme right-wing ideology of the so-called "Nationalist International." History textbooks would do well to transmit past generations' experience of living and navigating effectively through their own times of apparent change, new extremes, and growing unpredictability.

\section{Appendix: Textbooks Grouped by Country}

\section{Austria}

Ulrike Ebenhoch, Alois Scheucher, Eduard Staudinger, and Josef Scheipl, Zeitbilder: Geschichte und Sozialkunde/Politische Bildung. Maturatraining. . . (Wien, 2013).

Karl Vocelka, Andrea Scheichl, and Christian Matzka, Heinz Amler, and Christine Kreiner, ZeitenBlicke: Geschichte und Sozialkunde, Politische Bildung 3 (Wien, 2010).

Elisabeth Buxbaum, Erlebnis Zeitreise (Wien, 2002).

Oskar Achs, Manfred Scheuch, and Eva Tesar, Gestern, heute, morgen: aus Geschichte lernen. 7. Klasse, Das 20. Jahrhundert (Wien, 2005).

Erlefried Schröckenfuchs and Gerhard Huber, Einst und heute: Geschichte und Sozialkunde 8 (Wien, 2002).

Michael Eigner, Zeitzeichen-Geschichte und Kultur (Linz, 2007).

\section{Belarus}

E.K. Novik, ed., Istoriia Belarusi XIX-nachalo XXI v. (Minsk, 2009).

V.S. Koshelev, ed., Vsemirnaia istoriia, XIX-nachalo XXI v. (Minsk, 2009). 
I. Kovkel' and E.S. Iarmusik, Istoriia Belarusi s drevneishikh vremen do nashego vremeni (Minsk, 2010).

N. Sharova, Istoriia Belarusi. Opornye konspekty dlia podgotovki k tsentralizovannomu testirovaniiu (Minsk, 2010).

N.S. Stashkevich, G.Y. Golenchenko, and I.I. Bogdanovich, Istoriia Belarusi. Posobie dlia podgotovki k tsentralizovannomu testirovaniiu (Minsk, 2012).

N.M. Purysheva and M.I. Starovoitova, Istoriia Belarusi. Shkol'nyi kurs v kratkom izlozhenii (Minsk, 2012).

\section{Belgium}

Denise Galloy and Franz Hayt, Histoire du temps present. L'Europe et le monde de 1914 à nos jours (Brussels, 2007).

Jean-Louis Jadoulle and André Tihon, Racines Du Futur. Tome II, Du XVIIIe siècle à 1918 (Brussels, 1992).

Xavier Adams and Leon van Cuppens, Anno 5 (Lier, 2001).

Kristel Bekers, Jacky Philips, Kris Merckx, Storia. 5 ASO: leerboek (Lier, 2001).

\section{Bosnia and Herzegovina}

Zijad Šehić, Zvjezdana Marčić-Matošević, and Alma Leka, Historija, istorija, povijest: udžbenik i čitanka za 8. razred osnovne škole (Sarajevo, 2007).

Stjepan Bekavac, Siniša Kljajić, and Miroslav Rozić, Povijest: Udžbenik $z a$. . . razred osnovne škole. 7, Udžbenik (Mostar, 2009).

Aida Petković and Marina Pocrnja. Historija 7. (Sarajevo, 2012).

Ranko Pejic, Istorija $1 \mathrm{Za}$ I razred srednjih stručnih škola (Sarajevo, 2006).

Ranko Pejić, Simo Tešić, and Stevo Gavrić, Udžbenik istorije za 9. razred osnovnih škola u entitetu Republika Srpska (Sarajevo, 2007).

Hrvoje Matković, Udžbenik za 4. razred gimnazije (Mostar, 2003).

\section{Bulgaria}

Petr Delev et al. Istorija na Bulgariia: Za 11. Klas (Sofia, 1999).

Daniel Vačkov, Istoriia na novoto vreme 1492-1918: 9 klas (Sofia, 2000).

Rajna Gavrilova, Marija Radeva, Evgenija Kalinova, Istoriia i civilizaciia za 6. Klas (Sofia, 2007).

Milijana Kajmakamova, Plamen Mitev, Ljubomir Ognjanov, and Milcho Dalkov, Istoriia na Bulgariia za kandidat-studenti i zrelostnici (Sofia, 2008).

Milena Kalfova, Istoriia na Bulgariia za zrelostnici i kandidat-studenti (Sofia, 2008).

\section{Czech Republic}

Milan Hlavačka, Jan Kuklík, and Petr Čornej, Dějepis: pro gymnázia a střední školy. 4, Nejnovější dějiny (Prague, 2005).

Veronika Valková, Dějepis: pro základní školy: Pravěk a starověk, (Prague, 2008). 
Petr Čornej, Ivana Čornejová, František Parkan, and Milan Kudrys, Dějepis pro střední odborné školy: České a světové dějiny (Prague, 2016).

František Parkan, Tomáš Mikeska, and Markéta Parkanová, Dějepis: Pro základní školy a víceletá gymnázia. 9, učebnice [Moderní doba] (Plzeň, 2011).

\section{France}

Jacques Bordes, Jean-Louis Nembrini, and Pierre Polivka, Pour connaître la France (Paris, 2000).

Jean-Pierre Lauby, Michel Promérat, and François Sirel Magnard, Histoire, le monde contemporain du milieu du XIXe siècle à 1945 (Paris, 2007).

Bruno Barbier, Henri Bernard, and Bernard Binoist, Le monde contemporain du milieu du XIXe siècle à 1945: 1resES, L/S (Paris, 2003).

Serge Berstein and Pierre Milza, Histoire de l'Europe: Du XIXe siècle au début du XXIe siècle (Paris, 2006).

Jean-Michel Lambin, Catherine Cassagne, Odile Louage, Marie-Anne Matard-Bonucci, Hélène Sadowski, Jean-François Sirinelli, Marcel Spisser, Robert Steegmann, Anne Vannouque, Jean Vassort, Jean-Luc Villette, and Nicolas Werth, Histoire Premières ES / L / S-Livre de l'élève (Paris, 2003).

\section{Germany}

Dieter Brückner et al., Geschichte erleben 4: Für sechsstufige Realschulen Gebundene Ausgabe (Bamberg, 2003).

Jan Kulok, Geschichte und Geschehen: Topic book. Oberstufe. Inter-War Europe, 1918-1939 (Berlin, 2012).

Anton Egner, Thema. Geschichte. Das 19. Jahrhundert. Nationsbildung und Modernisierung (Braunschweig, 2007).

Peter Geiss, Daniel Henri, and Guillaume Le Quintrec, Histoire l'Europe et le monde du Congrès de Vienne à 1945: Manuel d'histoire franco-allemand, premières L-ES-S (Paris, 2008).

Böhm Jürgen and Markus Freundorfer, Zeitreise / Realschule / Bayern. 1. Aufl., 2. Dr. Vol. 4 (Stuttgart, 2011).

Mitmischen A, [Unterrichtswerk Für Den Geschichtsunterricht an HauptUnd Gesamtschulen] 3 (Stuttgart, 2009).

\section{Ireland}

Patricia McCarthy and Kevin McCarthy, Footstepsin Time:Junior Certificate History (Dublin, 2010).

Dermot Lucey, The Past Today: Complete Junior Certificate History (Dublin, 2002).

Vincent Foley, The Pursuit of Sovereignty and the Impact of Partition, 191249 (Dublin, 2010).

M.E. Collins, Henry Gráinne, Stephen Tonge, Living History 2: A Complete Course for the Junior Certificate (Dublin, 2004). 
Italy

Vittoria Calvani and Paola Brengola, Finestre sulla storia 3: Dell'eta della globalizzazione (Milan, 2010).

Vittorio Beonio-Brocchieri, Simona Colarizzi, and Guido Martinotti, La memoria e il tempo. La memoria e il tempo: Dal basso Medioevo all'eta contemporanea 3, Il secolo 20 e le prospettive del secolo 21 (Milan, 2009).

Antonio Brancati and Trebi Pagliarani, Tanti tempi, una storia 3 (Milan, 2006).

Carlo Cartiglia, Il tempo e il racconto. Risorse per l'insegnante (Turin, 2014).

Giorgio De Vecchi and Giorgio Giovannetti. Storia in corso: Società, economia, cultura materiale 1. Dal medioevo alla formazione dell'Europa moderna (Milan, 2012).

Carlo Cartiglia, Storia e ricerca (Turin, 2002).

Gianni Gentile and Luigi Ronga. Navigare nella storia. Per la Scuola media: 3 (Brescia, 2003).

\section{Luxembourg}

Marie-Paule Eyschen, Entdecken und Verstehen: Geschichtsbuch für den Technischen Sekundarunterricht in Luxemburg 3 (Berlin, 2009).

\section{Macedonia}

Violeta Ačkoska, Fejzula Šabani, and Vančo Ǵorğiev, Istorija za sedmo oddelenie (Skopje, 2016).

Blaže Ristovski, Šukri Rahimi, and Simo Mladenovski, Istorija: za treta godina gimnazisko obrazovanie (Skopje, 2006).

Kosta Adžievski, Istorija: za petto oddelenie (Skopje, 2007).

Vlado Velkoski, Dimka Risteska, and Gorgi Pavlovski, Rabotni listovi po istorija: za VIII oddelenie (Skopje, 2005).

\section{Montenegro}

Šerbo Rastoder, Radoje Pajović, and Zvezdan Folić, Istorija 4: Za IV razgred gimnazje (Belgrade, 2006).

Slavko Burzanović and Jasmina Đorđević, Istorija 9: Za deveti razred devetogodišnje osnovne škole (Belgrade, 2008).

\section{Poland}

Elżbieta Centkowska and Jerzy Centkowski, Historia i społeczeństwo: Program nauczania dla klas 4-6 szkoły podstawowej (Warsaw, 2000).

Piotr Galik, IlonaZaleska, and Aneta Niewęgłowska, Zrozumiećprzeszłość: Lata 1815-1939: podręcznik do historii dla liceum ogólnoksztatcącego i technikum: Zakres rozszerzony. Cz. 3 (Warsaw, 2014).

Zofia T Kozłowska, Poznajemy przeszłość od początku xviii w. do 1939 roku: Podręcznik dla liceum ogólnokształcacego, liceum profilowanego i technikum : zakres podstawowy (Toruń, 2010). 
Grzegorz Szymanowski and Piotr Trojański, Ludzie i epoki: Historia klasa 3, podręcznik do historii obejmujacy ksztatcenie $w$ zakresie podstawowym $w$ liceum ogólnokształcacym, liceum profilowanym i technikum oraz kształcenie $w$ zakresie rozszerzonym $w$ liceum ogólnokształcacym i liceum profilowanym (Kraków, 2004).

Włodzimierz Mędrzecki and Robert Szuchta, U źródeł współczesności: Dzieje nowożytne i najnowsze: historia 3: zeszyt ćwiczeń (Warsaw, 2007).

Tomasz Małkowski and Jacek Rześniowiecki, Historia: Podręcznik do gimnazjum 3, podręcznik podręcznik dla klasy iii gimnazjum (Gdańsk, 2011).

Halina Tomalska, Polska i świat w XIX wieku: Historia, podręcznik dla gimnazjum (Warsaw, 2001).

\section{Portugal}

Célia Pinto do Couto and Maria Antónia Monterroso Rosas, $O$ tempo da história: História, . . . ano de escolaridade Ano 12, Vol. 2 (Porto, 2003).

Natércia Crisanto, Isabel Simões, and J. Amado Mendes, Novo história: História . . . ano de escolaridade Ano 8, Caderno do aluno (Porto, 2000).

Eliseu Alves, História Ano 8 (Porto, 1999).

Pedro Almiro Neves, Novo Clube de história: Historia ... ano Ano 9, Caderno de actividades (Porto, 2004).

Natércia Crisanto, J. Amado Mendes, and Isabel Simões, História 90 ano (Porto, 2005).

Aníbal Barreira and Mendes Moreira, Rumos da história: História 3, ciclo do Ensino Básico Ano 9 (Porto, 2004).

\section{Serbia}

Nikola L. Gaćeša, Dušan Živković, and Ljubica Radović, Istorija: Za II razred četvorogodišnjih stručnih škola (Belgrade, 2002).

Radoš Ljušić, Istorija: Za treći razred gimnazije opšteg i društveno-jezičkog smera (Belgrade, 2013).

Branka Bečanović, Jelena Jevrić, and Zvezdana Petrović, Istorija 7: Udžbenik za sedmi razred osnovne škole (Belgrade, 2011).

Đorđe Đurić and Momčilo Pavlović, Istorija 8: Za osmi razred osnovne škole (Belgrade, 2010).

\section{Slovakia}

Alena Bartlová and Róbert Letz, Národné dejiny (Bratislava, 2008).

Dušan Kováč. Dejepis: Pátrame po minulosti. Pre 9. ročník ZŠ a 4. ročník gymnázia s osemročným štúdiom (Bratislava, 2012).

Viliam Kratochvíl and Miroslav Daniš, Denník $z$ pátrania po minulosti cvičebnica dejepisu pre 5. ročník základnej školy (Bratislava, 2010).

\section{Slovenia}

Ana Nuša Kern, Dušan Nećak, Božo Repe, Roman Vogrinc, Mateja Rihtaršič, Davor Grgičević, Roman Brvar, and Karmen Pajk, Naše stoletje 
zgodovina za 9. razred osnovne šole: Učbenik, prilagojen za slabovidne učence (Ljubljana, 2007).

Božo Repe and Mateja Rihtaršič, Sodobna zgodovina: Zgodovina za 4. letnik gimnazij (Ljubljana, 2008).

Ervin Dolenc, Marjan Rode, and Aleš Gabrič, Koraki v času. 20. stoletje: Zgodovina za 9. razred devetletke (Ljubljana, 2010).

\section{Spain}

Julio Montero Díaz, Historia de España contemporánea (Zaragoza, 2000). Ángel Bahamonde Magro and Luis Enrique Otero Carvajal, Historia de España: $2^{\circ}$ Bachillerato (Madrid, 2009).

Juan Santacana and Gonzalo Zaragoza, Milenio: historia, secundaria ciencias sociales, ciclo 2 (Madrid, 2000).

Manuel Burgos Alonso, Historia: 1er ciclo (Madrid, 2000). 2003).

Julio Aróstegui, Perspectiva: Història del món contemporani (Barcelona,

Julio Aróstegui, Panorama: Historia; bachillerato, segundo curso (Barcelona, 2002).

\section{Switzerland}

Regula Argast, Alexandra Binnenkade, Felix Boller, and Peter Gautsch, Viele Wege-eine Welt, Erster Weltkrieg bis Globalisierung (Bern, 2016).

Christophe Gross, Schweizer Geschichtsbuch. 3/4, Kompaktausgabe: Vom Ersten Weltkrieg bis zur Gegenwart (Berlin, 2011).

\section{United Kingdom}

Andrew Wrenn, The First World War (Cambridge, 1997).

Colin Shephard, Andy Reid, and Keith Shephard, Peace and War: Pupil's Book. Year 9 (London, 1993).

Rosemary Rees and Nigel Kelly, Modern World (Oxford, 2001).

Liz Petheram, Britain in the 20th Century (Cheltenham, 2001).

Allan Todd, The Modern world (Oxford, 2001).

\section{Ukraine}

F.H. Turchenko, Novitnia istoriia Ukraïny, 1914-1939 (Kyiv, 2004).

Pavel Polianskii, Vsemirnaia istoriia 10 klass (Kyiv, 2010).

T.V. Ladichenko, S.O. Osmolovs' kii. Vsesvitnia istoriia 10 klas (Kyiv, 2010).

Iaroslav Hrytsak, Narisi istoriïUkrä̈ny: Formuvannia modernoüukraïns' koï natsiï XIX-XX st. (Kyiv, 1996). 